\title{
Synthesis, Characterization and Antimicrobial Activity of 4-Oxo- thiazolidines and 5-Arylidene Derivatives of 2-Methylimidazoles
}

\author{
Rajiv Dua, ${ }^{@}$ S. K. Srivastava, and S. D. Srivastava \\ Synthetic Organic Medicinal Chemistry Laboratory, Department of Chemistry, Dr. H.S. Gour University, Sagar (M.P.), \\ India. \\ ${ }^{\circledR}$ Corresponding author E-mail: duanobleheights@gmail.com
}

\begin{abstract}
As a part of systematic investigation of synthesis and biological activity of 4-oxothiazolidines and their 5-arylidene derivatives several [ $N^{I}$-(2-aryl-4-oxo-1,3-thiazolidinylamino)acetyl]-2-methylimidazoles 4a-j and [NI-(5-arylidene2-aryl-4-oxo-1,3-thiazolidinylamino)acetyl]-2-methylimidazoles 5a-j have been synthesized from $N^{1}$-(hydrazinoacetyl)-2-methylimidazole, 2, using 2-methylimidazole as the starting material. All the synthesized products were evaluated for their antifungal activity against Aspergillus niger, Aspergillus flavus, Fusarium oxisporium and Trichoderma viride and antibacterial activity against Bacillus substilis, Escherichia coli, Klebsiella pneumoneae and Streptococcus aureus respectively. The structures of all the synthesized compounds have been determined by their spectral and microanalytical data.
\end{abstract}

Keywords: 2-Methylimidazole, arylidenes, 4-oxothiazolidines, antimicrobial activity.

\section{Introduction}

Heterocycles form by far the largest of classical divisions of organic chemistry and are of immense importance biologically and industrially. The majority of pharmaceuticals and biologically active agrochemicals are heterocyclic while countless additives and modifiers used in industrial applications ranging from cosmetics, reprography, information storage and plastics are heterocyclic in nature. ${ }^{[1]}$ From time immemorial, organic chemists have been attemp-ting to synthesize, isolate and characterize new heterocyclic molecules for their unique chemical and physical properties. Despite the fact that many convenient methods have been utilized for preparing the basic heterocycles ${ }^{[2]}$ elaboration of new synthetic approaches remains very important. Among the many possible targets five-membered heterocyclic derivatives such as imidazole are of particular interest. For instance, naturally occurring 4-substituted imidazoles such as histidine or histamine and their significance as an essential amino acid or its decarboxylation product, are well known. ${ }^{[3]}$ Imidazole chemistry currently attracts considerable attention, where the imidazole derivatives possess various types of broad spectrum biological activities such as antimicrobial, ${ }^{[4-6]}$ antiprotozoal, ${ }^{[7]}$ antitumor, ${ }^{[8]}$ anti-HIV, ${ }^{[9]}$ analgesic and antiinflammatory, ${ }^{[10]}$ etc. 4-Oxo-thiazolidines and their 5-arylidene derivatives also possess a variety of therapeutic activities such as antimicrobial, ${ }^{[11,12]}$ antiinflammatory, ${ }^{[13,14]}$ and antitubercular, ${ }^{[15]}$ etc. The incorporation of 4-oxo-thiazolidines and their 5 -arylidene moiety in imidazole framework has been found to enhance the activity. Thus considering all these biologically important properties of such types of compounds, different types of imidazole derivatives were prepared. By considering the above arguments, we have synthesised several new $\left[N^{1}\right.$-( $N$-arylidenehydrazino)acetyl $]-2$-methylimidazoles (3a-j), [N1-(2-aryl-4-oxo-1,3-thiazolidinylamino)acetyl]-2- methylimidazoles (4a-j) and $\left[N^{1}\right.$-(5-arylidene-2-aryl-4-oxo1,3-thiazolidinyl-amino)-acetyl]-2-methyl-imidazoles (5a-j) by appropriate methods. All the synthesized compounds have been screened for their antibacterial activity against $B$. substilis, E. coli, S. aureus and K. pneumoniae bacteria and antifungal activity against $A$. niger, A. flavus, F. oxisporium and $T$. viride fungi respectively.

\section{Experimental}

Melting points were taken in open capillaries and are uncorrected. Purity of compounds was monitored on silica gel ' $G$ ' coated TLC plates. IR spectra were recorded on Schimadzu 8201 $\mathrm{PC}$ spectrophotometer in $\mathrm{KBr}$ and ${ }^{1} \mathrm{H}$ NMR spectra - on Brucker DRX 300 spectrometer in $\mathrm{CDCl}_{3}$ at $300 \mathrm{MHz}$ using TMS as an internal standard. The reagent grade chemicals were purchased from commercial sources and purified by either distillation or recrystallization before use.

$N^{I}$-(chloroacetyl)-2-methylimidazole, 1: The equimolar solution of 2-methylimidazole $(0.80 \mathrm{~mol}, 65.68 \mathrm{~g})$ and chloroacetyl chloride $(0.80 \mathrm{~mol}, 90.35 \mathrm{~g})$ in methanol $(300 \mathrm{ml})$ was refluxed on water bath for about $4 \mathrm{hrs}$, cooled, filtered, washed with ice-cooled water and purified over the column of silica gel using chloroform: acetone $(7: 3 \mathrm{v} / \mathrm{v})$ mixture as an eluent. The eluate was concentrated to give a product, which was recrystallized from ethanol to give compound 1. Yield $87 \%$. m.p. $112-14^{\circ} \mathrm{C}$. Found: C 40.91, H 4.76, $\mathrm{N} 19.03 \% . \mathrm{C}_{5} \mathrm{H}_{7} \mathrm{~N}_{2} \mathrm{OCl}$ requires C 40.97, $\mathrm{H} 4.81, \mathrm{~N} 19.11 \%$. IR v $\mathrm{cm}^{-1}: 2986(v(\mathrm{CH})), 2954\left(\mathrm{v}\left(\mathrm{CH}_{2}\right)\right), 2871\left(\mathrm{v}\left(\mathrm{CH}_{3}\right)\right), 1663(>\mathrm{NCO})$, $1603(\mathrm{v}(\mathrm{C}=\mathrm{C})), 1582(-\mathrm{C}=\mathrm{N}), 769(\mathrm{v}(\mathrm{CCl})) .{ }^{1} \mathrm{H}$ NMR $\delta_{\mathrm{H}} \mathrm{ppm}: 2.43$ $\left(\mathrm{s}, 3 \mathrm{H},-\mathrm{CH}_{3}\right), 6.97\left(\mathrm{~d}, J=5.8 \mathrm{~Hz}, 1 \mathrm{H}, \mathrm{C}^{4} \mathrm{H}\right), 7.13(\mathrm{~d}, \mathrm{~J}=5.8 \mathrm{~Hz}, 1 \mathrm{H}$, $\left.\mathrm{C}^{5} \mathrm{H}\right), 4.56\left(\mathrm{~s}, 2 \mathrm{H},-\mathrm{CH}_{2}\right)$.

$N^{I}$-(hydrazinoacetyl)-2-methylimidazole, 2: The compound $1(0.38 \mathrm{~mol}, 55.7 \mathrm{~g})$ and hydrazine hydrate $(0.38 \mathrm{~mol}, 19.02 \mathrm{~g})$ in methanol $(250 \mathrm{ml})$ was refluxed on a water bath for about 6 hours. It was cooled and filtered to get a product which was purified over the column of silica gel using chloroform:acetone $(3: 2 \mathrm{v} / \mathrm{v})$ mixture as an eluent. The eluate was concentrated, the product was recrystallized from chloroform to give compound 2 . Yield 
$81 \%$. m.p. $143-45^{\circ}$ C. Found: C 42.17, H 7.07, N $39.37 \%$. $\mathrm{C}_{5} \mathrm{H}_{10} \mathrm{~N}_{4} \mathrm{O}$ requires C 42.24, $\mathrm{H} 7.09$, N $39.41 \%$. IR $v \mathrm{~cm}^{-1}: 3456,3412,3368$, $3274\left(-\mathrm{NHNH}_{2}\right), 2949\left(-\mathrm{CH}_{2}\right), 2981(\mathrm{v}(-\mathrm{CH})), 2866\left(-\mathrm{CH}_{3}\right),, 1666$ $(>\mathrm{N}-\mathrm{CO}), 1597(\mathrm{v}(\mathrm{C}=\mathrm{C})), 1584(\mathrm{C}=\mathrm{N}) .{ }^{1} \mathrm{H}$ NMR $\delta_{\mathrm{H}} \mathrm{ppm}: 8.39(\mathrm{~s}$, $1 \mathrm{H},-\mathrm{NH}), 4.90\left(\mathrm{~s}, 2 \mathrm{H},-\mathrm{NH}_{2}\right), 2.45\left(\mathrm{~s}, 3 \mathrm{H},-\mathrm{CH}_{3}\right), 6.94(\mathrm{~d}, \mathrm{~J}=5.8$ $\left.\mathrm{Hz}, 1 \mathrm{H}, \mathrm{C}^{4} H\right), 7.14\left(\mathrm{~d}, \mathrm{~J}=5.8 \mathrm{~Hz}, 1 \mathrm{H}, \mathrm{C}^{5} H\right), 4.52\left(\mathrm{~s}, 2 \mathrm{H},-\mathrm{CH}_{2}\right)$.

[NI-(N-arylidenehydrazino)acetyl]-2-methylimidazoles, 3a-j: A mixture of compound $2(0.03 \mathrm{~mol}, 4.4 \mathrm{~g})$ and benzaldehyde $(0.03 \mathrm{~mol}, 3.18 \mathrm{~g})$ in methanol $(50 \mathrm{ml})$ with $4-5$ drops of acetic acid was refluxed on a water bath for about 1 hours. The solvent was distilled off under reduced pressure and the solid thus obtained was purified over the column of silica gel using chloroform:methanol $(1: 1 \mathrm{v} / \mathrm{v})$ mixture as an eluent. The eluate was concentrated to give a product, which was recrystallized with ethanol to give compound 3a. Yield $84 \%$. m.p. $156-58^{\circ} \mathrm{C}$. Found: $\mathrm{C} 62.55, \mathrm{H} 6.11, \mathrm{~N} 24.31$ $\%$. $\mathrm{C}_{12} \mathrm{H}_{14} \mathrm{~N}_{4} \mathrm{O}$ requires $\mathrm{C} 62.59, \mathrm{H} 6.12, \mathrm{~N} 24.33 \%$. IR $v \mathrm{~cm}^{-1}$ : $3354(-\mathrm{NH}), 2864\left(-\mathrm{CH}_{3}\right), 1546(-\mathrm{N}=\mathrm{CH}), 2982,1611,1583,733$ (imidazole ring) 3026, 1596, 739 (aromatic ring), 1670 (>NCO). ${ }^{1} \mathrm{H}$ NMR $\delta_{\mathrm{H}}$ ppm: $2.46\left(\mathrm{~s}, 3 \mathrm{H},-\mathrm{CH}_{3}\right), 4.81(\mathrm{~s}, 1 \mathrm{H},-\mathrm{NCH}), 8.34(\mathrm{~s}, 1 \mathrm{H}$, $-\mathrm{N} H), 7.29-7.82(\mathrm{~m}, 5 \mathrm{H}, \mathrm{Ar}-H), 4.53\left(\mathrm{~s}, 2 \mathrm{H},-\mathrm{CH}_{2}\right), 6.85(\mathrm{~d}, \mathrm{~J}=5.8$ $\left.\mathrm{Hz}, 1 \mathrm{H}, \mathrm{C}^{4} H\right), 7.13\left(\mathrm{~d}, \mathrm{~J}=5.8 \mathrm{~Hz}, 1 \mathrm{H}, \mathrm{C}^{5} H\right)$.

Likewise other compounds $\mathbf{3 b}$-j were synthesized by treating the compound 2 by selected aromatic aldehydes.

[N'-(2-aryl-4-oxo-1,3-thiazolidinylamino)acetyl]-2methylimidazoles, 4a-j: The compound 3a (6 mmol, $1.38 \mathrm{~g})$ and mercapto acetic acid $(6 \mathrm{mmol}, 0.55 \mathrm{~g})$ in methanol $(25 \mathrm{ml})$ with a pinch of anhydrous $\mathrm{ZnCl}_{2}$ was first stirred for about $2 \mathrm{hrs}$. followed by refluxing on a steam bath for about $15 \mathrm{hrs}$ and cooled. The solid thus obtained was filtered and purified on the column of silica gel using chloroform : methanol $(3: 2 \mathrm{v} / \mathrm{v})$ mixture as an eluent. The eluate was concentrated and the product was recrystallised with chloroform to give compound 4a. Yield 70\%. m.p. 206-08 ${ }^{\circ} \mathrm{C}$. Found: C 56.84, H 4.97, N $17.63 \% . \mathrm{C}_{15} \mathrm{H}_{16} \mathrm{~N}_{4} \mathrm{SO}_{2}$ requires $\mathrm{C} 56.90$, H 5.09, N $17.70 \%$. IR $v$ cm$^{-1}: 2986\left(-\mathrm{NCH}_{2} \mathrm{~S}\right), 1673(>\mathrm{C}=\mathrm{O}), 1726$ ( $>\mathrm{C}=\mathrm{O}$ cyclic), 3358 (-NH), 2972, 1612, 1576, 731 (imidazole ring), $2876\left(-\mathrm{CH}_{3}\right), 3019,1597,742$ (aromatic ring). ${ }^{1} \mathrm{H}$ NMR $\delta_{\mathrm{H}} \mathrm{ppm}$ : $3.79\left(\mathrm{~s}, 2 \mathrm{H},-\mathrm{CH}_{2} \mathrm{~S}\right), 2.42\left(\mathrm{~s}, 3 \mathrm{H},-\mathrm{CH}_{3}\right), 4.80(\mathrm{~s}, 1 \mathrm{H},-\mathrm{NCH}), 8.36$ $(\mathrm{s}, 1 \mathrm{H},-\mathrm{NH}), 7.29-7.80(\mathrm{~m}, 5 \mathrm{H}, \mathrm{Ar}-H), 4.54\left(\mathrm{~s}, 2 \mathrm{H},-\mathrm{CH}_{2}\right), 6.91$ $\left(\mathrm{d}, \mathrm{J}=5.8 \mathrm{~Hz}, 1 \mathrm{H}, \mathrm{C}^{4} H\right), 7.13\left(\mathrm{~d}, \mathrm{~J}=5.8 \mathrm{~Hz}, 1 \mathrm{H}, \mathrm{C}^{5} H\right)$.

Other compounds $\mathbf{4 b}$-j were synthesized in the similar manner using compounds $\mathbf{3} \mathbf{b}-\mathbf{j}$.

[NI-(5-arylidene-2-aryl-4-oxo-1,3-thiazolidinylamino) acetyl]-2-methylimidazoles, 5a-j: The compound 4 a (4 mmol, 1.26 $\mathrm{g})$ and benzaldehyde $(4 \mathrm{mmol}, 0.42 \mathrm{~g}$ ) in methanol $(25 \mathrm{ml})$ in the presence of sodium ethoxide was refluxed on water bath for about $3 \mathrm{hrs}$.The solvent was distilled off under reduced pressure and the solid thus obtained was purified on the column of silica gel using acetone : methanol $(4: 1 \mathrm{v} / \mathrm{v})$ as an eluent. The eluate was concentrated and the product was recrystallized with ethanol to give compound 5a. Yield $60 \%$. m.p. $163-65^{\circ} \mathrm{C}$. Found: C $65.32, \mathrm{H}$

Table 1. Antibacterial activity (inhibition zone diameter in $\mathrm{mm}$ ) of the synthesized compounds $\mathbf{3} \mathbf{a}-\mathbf{j}, \mathbf{4} \mathbf{a}-\mathbf{j}$ and $\mathbf{5 a} \mathbf{a} \mathbf{j}$.

\begin{tabular}{|c|c|c|c|c|c|c|c|c|}
\hline \multirow{2}{*}{ Comp. } & \multicolumn{2}{|c|}{ B. subtilis } & \multicolumn{2}{|c|}{ E. coli } & \multicolumn{2}{|c|}{$\underline{\text { K. pneumoniae }}$} & \multicolumn{2}{|c|}{$\underline{\text { S. aureus }}$} \\
\hline & $50 \mathrm{ppm}$ & $100 \mathrm{ppm}$ & $50 \mathrm{ppm}$ & $100 \mathrm{ppm}$ & $50 \mathrm{ppm}$ & $100 \mathrm{ppm}$ & $50 \mathrm{ppm}$ & $100 \mathrm{ppm}$ \\
\hline $3 \mathbf{a}$ & 8 & 10 & 6 & 11 & 7 & 12 & 4 & 7 \\
\hline $3 \mathbf{b}$ & 14 & 21 & 11 & 20 & 12 & 17 & 12 & 16 \\
\hline $3 c$ & 14 & 23 & 14 & 23 & 11 & 19 & 15 & 18 \\
\hline 3d & 19 & 28 & 16 & 24 & 14 & 21 & 16 & 26 \\
\hline $3 e$ & 16 & 26 & 16 & 23 & 14 & 20 & 16 & 24 \\
\hline $3 f$ & 12 & 23 & 13 & 20 & 12 & 18 & 15 & 20 \\
\hline $3 g$ & 14 & 24 & 11 & 19 & 11 & 16 & 14 & 19 \\
\hline $3 \mathrm{~h}$ & 11 & 18 & 10 & 16 & 12 & 17 & 13 & 22 \\
\hline $3 \mathbf{i}$ & 12 & 18 & 11 & 16 & 11 & 16 & 15 & 21 \\
\hline $3 \mathbf{j}$ & 15 & 20 & 13 & 18 & 10 & 19 & 14 & 22 \\
\hline $4 a$ & 12 & 11 & 8 & 12 & 13 & 18 & 13 & 20 \\
\hline $4 b$ & 14 & 21 & 16 & 20 & 14 & 18 & 12 & 22 \\
\hline $4 c$ & 16 & 22 & 15 & 23 & 13 & 19 & 14 & 24 \\
\hline $4 d$ & 18 & 26 & 18 & 25 & 17 & 22 & 17 & 26 \\
\hline $4 e$ & 16 & 24 & 17 & 24 & 14 & 21 & 16 & 24 \\
\hline $4 f$ & 14 & 25 & 16 & 22 & 11 & 18 & 15 & 19 \\
\hline $4 \mathrm{~g}$ & 14 & 26 & 15 & 22 & 10 & 17 & 14 & 22 \\
\hline $4 h$ & 12 & 23 & 13 & 16 & 12 & 22 & 13 & 20 \\
\hline $4 i$ & 11 & 22 & 11 & 15 & 13 & 21 & 12 & 21 \\
\hline $4 j$ & 16 & 24 & 15 & 21 & 16 & 23 & 15 & 22 \\
\hline $5 a$ & 12 & 13 & 12 & 20 & 13 & 19 & 10 & 20 \\
\hline $5 b$ & 16 & 22 & 13 & 20 & 12 & 18 & 12 & 24 \\
\hline $5 c$ & 16 & 22 & 15 & 23 & 10 & 17 & 13 & 22 \\
\hline $5 d$ & 18 & 24 & 16 & 24 & 14 & 23 & 16 & 26 \\
\hline $5 e$ & 16 & 24 & 14 & 23 & 14 & 22 & 17 & 24 \\
\hline $5 f$ & 12 & 26 & 12 & 22 & 14 & 20 & 16 & 22 \\
\hline $5 \mathrm{~g}$ & 12 & 23 & 15 & 20 & 19 & 23 & 14 & 21 \\
\hline $5 \mathrm{~h}$ & 14 & 21 & 13 & 22 & 12 & 17 & 15 & 20 \\
\hline $5 i$ & 11 & 20 & 11 & 20 & 13 & 17 & 17 & 23 \\
\hline $5 \mathbf{j}$ & 16 & 22 & 14 & 21 & 12 & 19 & 14 & 22 \\
\hline SM & 21 & 28 & 20 & 26 & 19 & 25 & 18 & 27 \\
\hline
\end{tabular}

SM $=$ Streptomycin 
4.94, $\mathrm{N} 13.82 \% . \mathrm{C}_{22} \mathrm{H}_{20} \mathrm{~N}_{4} \mathrm{O}_{2} \mathrm{~S}$ requires $\mathrm{C} 65.34, \mathrm{H} 4.95, \mathrm{~N} 13.86$ $\%$. IR $v \mathrm{~cm}^{-1}$ : 1621 (-C=CHAr), $3360(-\mathrm{NH}), 2981,1614,1586$, 732 (imidazole ring), $2872\left(-\mathrm{CH}_{3}\right), 3012,1591,746$ (aromatic ring), $1719\left(>\mathrm{C}=\mathrm{O}\right.$, cyclic), $1661(>\mathrm{C}=\mathrm{O}) .{ }^{1} \mathrm{H}$ NMR $\delta_{\mathrm{H}} \mathrm{ppm}: 4.82(\mathrm{~s}, 1 \mathrm{H}$, -NCH-), 5.27 (s, 1H, C=CHAr), 2.42 (s, 3H, $\left.-\mathrm{CH}_{3}\right), 8.37$ (s, 1H, -NH), 7.29-7.81 (m, 10H, Ar-H), $4.55\left(\mathrm{~s}, 2 \mathrm{H},-\mathrm{CH}_{2}\right), 6.91(\mathrm{~d}, \mathrm{~J}=5.8$ $\left.\mathrm{Hz}, 1 \mathrm{H}, \mathrm{C}^{4} \mathrm{H}\right), 7.12\left(\mathrm{~d}, \mathrm{~J}=5.8 \mathrm{~Hz}, 1 \mathrm{H},-\mathrm{C}^{5} \mathrm{H}\right)$.

The compounds $\mathbf{5 b}-\mathbf{j}$ were synthesized analogically by treating the compounds $\mathbf{4 b} \mathbf{b} \mathbf{j}$ with selected aromatic aldehydes.

\section{Antimicrobial Activity}

Antibacterial activity. All the synthesized compounds were evaluated in vitro for antibacterial activity by using filter paper disc method ${ }^{[16,17]}$ against different strains of bacteria viz. $B$. substilis, E. coli, S. aureus and K. pneumoniae. All the compounds along with standard antibacterial Streptomycin were used at 50 and 100 ppm concentrations.

Procedure. The solutions of known concentration (50 and 100 ppm) of the test sample were made by dissolving in DMSO. Dried and sterilized filter paper discs (6 $\mathrm{mm}$ in diameter) soaked with known amount of test agents were placed on the nutrient agar media solidified in Petri dishes (120 mm diameter) and inoculated with the test organisms. These plates were then kept at low temperature $\left(4^{\circ} \mathrm{C}\right)$ for 24 hours to allow maximum growth of the organisms. The antibacterial activity was determined by measuring the diameter of zone of inhibition in $\mathrm{mm}$. The antibacterial activity of the synthesized compounds $\mathbf{3} \mathbf{a}-\mathbf{j}, \mathbf{4} \mathbf{a}-\mathbf{j}$ and $\mathbf{5} \mathbf{a}-\mathbf{j}$ are given in Table 1 .

Antifungal activity. All the compounds were also assayed in vitro for antifungal activity against $A$. niger, A. flavus, $F$. oxisporium and $T$. viride fungi employing the filter paper disc method by measuring inhibition zone in $\mathrm{mm}$. All the tested compounds along with standard fungicide Griseofulvin were used at 50 and 100 ppm concentrations.

Procedure. The test samples were dissolved in DMSO to make 50 and $100 \mathrm{ppm}$ concentration solutions. Sterilized symmetrical filter paper discs of $6 \mathrm{~mm}$ diameter were taken in a blank Petri dishes. Sample solution $10 \mu \mathrm{m} /$ discs were applied on the discs with the help of a micropipette in an aseptic condition. The discs were left for a few minutes in the aseptic condition for complete removal of the solvent. Isolated spore (4-6 similar) of a pure fungus was inoculated in screw capped tube containing equal amount of potato dextrose agar (PDA) media and incubated at $28^{\circ} \mathrm{C}$ for 5-7 days for development of new pure culture that was used as inoculum. PDA medium was steamed to dissolve and dispersed $4 \mathrm{ml}$ amount of it into a Petri dish. It was then autoclaved at $121^{\circ} \mathrm{C}$ for 15 minutes. It was allowed to cool up to $30^{\circ} \mathrm{C}$ until the media became solid. The contents of each Petri dish was inoculated with different types of inoculums removed from a seven days old culture fungus. Dried and sterile sample discs and a standard (Fungal) disc were placed

Table 2. Antifungal activity (inhibition zone diameter in $\mathrm{mm}$ ) of the synthesized compounds $\mathbf{3} \mathbf{a}-\mathbf{j}$, $\mathbf{4 a - j}$ and $\mathbf{5 a - j}$.

\begin{tabular}{|c|c|c|c|c|c|c|c|c|}
\hline \multirow{2}{*}{ Comp. } & \multicolumn{2}{|c|}{ A. niger } & \multicolumn{2}{|c|}{$\underline{\text { A. flavus }}$} & \multicolumn{2}{|c|}{ F. oxisporium } & \multicolumn{2}{|c|}{$\underline{\text { T. viride }}$} \\
\hline & $50 \mathrm{ppm}$ & $100 \mathrm{ppm}$ & $50 \mathrm{ppm}$ & $100 \mathrm{ppm}$ & $50 \mathrm{ppm}$ & $100 \mathrm{ppm}$ & $50 \mathrm{ppm}$ & $100 \mathrm{ppm}$ \\
\hline $3 \mathrm{a}$ & 4 & 7 & 5 & 8 & 4 & 8 & 5 & 8 \\
\hline $3 b$ & 10 & 16 & 12 & 21 & 10 & 18 & 16 & 20 \\
\hline $3 c$ & 11 & 21 & 15 & 22 & 11 & 19 & 10 & 18 \\
\hline $3 d$ & 16 & 25 & 15 & 23 & 13 & 21 & 18 & 26 \\
\hline $3 \mathrm{e}$ & 14 & 22 & 14 & 22 & 12 & 20 & 16 & 20 \\
\hline $3 f$ & 13 & 21 & 12 & 20 & 11 & 19 & 14 & 25 \\
\hline $3 g$ & 14 & 22 & 17 & 22 & 14 & 21 & 16 & 20 \\
\hline $3 \mathrm{~h}$ & 16 & 23 & 14 & 22 & 15 & 23 & 22 & 27 \\
\hline $3 \mathrm{i}$ & 14 & 24 & 11 & 16 & 13 & 17 & 20 & 24 \\
\hline $3 \mathrm{j}$ & 16 & 26 & 16 & 24 & 15 & 24 & 22 & 26 \\
\hline $4 a$ & 12 & 11 & 8 & 12 & 14 & 19 & 13 & 17 \\
\hline $4 b$ & 14 & 21 & 12 & 20 & 13 & 21 & 12 & 18 \\
\hline $4 c$ & 12 & 20 & 13 & 19 & 14 & 24 & 14 & 20 \\
\hline $4 d$ & 14 & 25 & 16 & 23 & 19 & 26 & 19 & 24 \\
\hline $4 \mathrm{e}$ & 14 & 24 & 14 & 22 & 16 & 25 & 20 & 25 \\
\hline $4 f$ & 12 & 22 & 12 & 20 & 12 & 24 & 18 & 23 \\
\hline $4 \mathrm{~g}$ & 14 & 24 & 14 & 22 & 16 & 25 & 20 & 26 \\
\hline $4 \mathrm{~h}$ & 16 & 28 & 18 & 24 & 18 & 27 & 22 & 27 \\
\hline $4 \mathrm{i}$ & 11 & 26 & 11 & 16 & 13 & 22 & 20 & 25 \\
\hline $4 j$ & 19 & 27 & 19 & 26 & 19 & 28 & 22 & 28 \\
\hline $5 a$ & 12 & 13 & 12 & 19 & 12 & 20 & 16 & 22 \\
\hline $5 b$ & 16 & 20 & 13 & 20 & 17 & 22 & 12 & 28 \\
\hline $5 c$ & 12 & 21 & 15 & 22 & 18 & 23 & 15 & 22 \\
\hline $5 \mathrm{~d}$ & 16 & 22 & 16 & 26 & 19 & 25 & 20 & 24 \\
\hline $5 \mathrm{e}$ & 14 & 23 & 14 & 25 & 16 & 24 & 18 & 25 \\
\hline $5 f$ & 16 & 24 & 12 & 24 & 14 & 20 & 16 & 24 \\
\hline $5 \mathrm{~g}$ & 14 & 23 & 14 & 26 & 16 & 23 & 18 & 24 \\
\hline $5 \mathrm{~h}$ & 18 & 26 & 18 & 28 & 21 & 27 & 21 & 26 \\
\hline $5 \mathrm{i}$ & 11 & 22 & 11 & 16 & 15 & 22 & 20 & 22 \\
\hline $5 \mathrm{j}$ & 18 & 26 & 18 & 27 & 22 & 28 & 22 & 26 \\
\hline GF & 23 & 27 & 22 & 29 & 24 & 30 & 24 & 29 \\
\hline
\end{tabular}


<smiles></smiles>

(1)

(2)<smiles>Cc1nccn1C(=O)CNC=NCBr</smiles>

$3(a-j)$<smiles>Cc1nccn1CCO[Na]</smiles>

$4(a-j)$<smiles>C=C1SC([Al])NC1=O</smiles>

Ar $=$ Substituted aryl groups

3, 4, 5 (a): $\mathrm{Ar}=\mathrm{C}_{6} \mathrm{H}_{5}$
3, 4, 5 (b): $\mathrm{Ar}=2-\mathrm{CIC}_{6} \mathrm{H}_{4}$
3, 4, 5 (c): $\mathrm{Ar}=3-\mathrm{ClC}_{6} \mathrm{H}_{4}$
3, 4, 5 (d): $\mathrm{Ar}=4-\mathrm{ClC}_{6} \mathrm{H}_{4}$

Scheme 1.

on nutrient agar plates seeded with the test organism. These were then kept at low temperature $\left(4^{\circ} \mathrm{C}\right)$ for 24 hours to allow maximum diffusion. Finally the contents of all Petri dishes was inoculated at $27-28^{\circ} \mathrm{C}$ for $5-7$ days. The activity was justified by meaning of the diameter of inhibition zone in $\mathrm{mm}$. The antifungal activity of the synthesized compounds $\mathbf{3} \mathbf{a}-\mathbf{j}, \mathbf{4} \mathbf{a}-\mathbf{j}$ and $\mathbf{5} \mathbf{a}-\mathbf{j}$ are given in Table 2 .

\section{Results and Discussion}

2-Methylimidazole on reaction with chloroacetyl chloride yielded $N^{1}$-(chloroacetyl)-2-methylimidazole, $\mathbf{1}$, which on amination with hydrazine hydrate afforded $N^{1}$ (hydrazinoacetyl)-2-methylimidazole, 2. The compound $\mathbf{2}$ on condensation with various selected aromatic aldehydes yielded [N1-(N-arylidenehydrazino)acetyl $]-2-m e t h y l i m i d a-$ zoles, 3a-j. The compounds $\mathbf{3 a - j}$ on treatment with mercaptoacetic acid underwent dehydrative annulation in the presence of anhydrous $\mathrm{ZnCl}_{2}$ to afford [ $N^{1}$-(2-aryl-4-oxo1,3-thiazolidinylamino)acetyl]-2-methylimidazoles, 4a-j. The compounds $\mathbf{4 a - j}$ after treatment by aromatic aldehydes in the presence of sodium ethoxide gave [ $N^{1}$ - $(5$-arylidene-2aryl-4-oxo-1,3-thiazolidinylamino)acetyl]-2-methylimidazoles, 5a-j. The steps involved in the synthesis are shown in the Scheme 1. Their structures have been elucidated on the basis of their spectral and microanalytical data.

Acknowledgement. The authors are thankful to SAIF, CDRI Lucknow for providing spectral and analytical data of the compounds. We are also grateful to Dr. Mrs. Archana Tiwari, Department of Biotechnology, Dr. H. S. Gour University, and Sagar for providing help in carrying out the antimicrobial screening. We are also grateful to Head of the Department of Chemistry of this University for giving the facilities to carry out the work.

\section{References}

1. Kumar R., Joshi Y. C. E-J. Chem. 2007, 4(4), 606-610.

2. Katritzky A.R., Pozharskii A.F. Handbook of Heterocyclic Chemistry, 2nd ed. New York: Pergamon, 2000.

3. Yanai K, Tashiro M. Pharmacol. Ther. 2007, 113(1), 1-15.

4. Wiglenda T., Gust R, J. Med. Chem. 2007, 50, 1475-1484.

5. Kadriye B., Ahmet C.K., Klymet G. Arch. Pharmacal Res. 2003, 26(10), 773-777.

6. Wolf M.E. Burgens Medicinal Chemistry and Drugs Discovery, 5th ed. New York: John Wiley and Sons 1997, Vol 4, 429432.

7. Benakali K., Terme T., Vanelle P. Molecules 2002, 7, 382385 .

8. Al-Masoudi N.A, Al-Soud Y.A., Kalogerakis A., De-Clercq E. Chem. Biodiver. 2006, 3, 515-526.

9. Al-Masoudi N.A, Al-Soud, Yaseen, De-Clercq E. Acta Pharm. 2007, 57, 379-393.

10. Fatimi J., Lagorce J.F., Duroux J.L., Chabernaud M.L., Buxeraud J., Raby C. Chem. Pharm. Bull. (Tokyo) 1994, 42(3), 698-701.

11. Yadav R., Srivastava S.D., Srivastava S.K. Indian J. Chem. 2005, 44B, 1-5.

12. Viswajanani J.S, Soni A., Singhal S., Khan S., Pandya M. ARKIVOC II 2005, 46-59.

13. Patel N.B., Patel N .V. Iranian J. Pharma. Res. 2007, 6(4), 251-258

14. Bahekar S.S, Shinde D.B. J. Korean Chem. Soc. 2003, 47(3), 237-240.

15. Verma A., Saraf S.K. Eur. J. Med. Chem. 2008, 43(5), 897905

16. Ochei J., Kolhatkar A. Medicinal Laboratory Science-Theory and Practices New Delhi: Tata McGrow-Hill Publishing Co. Ltd. 2000, 808-818.

17. Labouta I.M., Solana H.M, Escba N.H, El-Chrbini E. Eur. J. Med. Chem. 1987, 72, 485-487. 